\title{
THE INTRODUCTION OF RELIGION TO POLITICS AND THE CONSTITUTIONAL FRAMEWORK AND THE AFTERMATH: A CRITICAL OVERVIEW OF THE HISTORY OF PRE AND POST BANGLADESH ERAS
}

\begin{abstract}
Drawing from historical narratives (from 1900-2011) of pre and post Bangladesh eras, the article shows how colonial rule, political parties and military rulers used religion and religious identity in public affairs, the constitution and politics, which eventually caused grave social disorder (characterised by communal dissent, communal violence, the partition of territory, secession and mass killings, political polarization and inception of religious hegemony) in the Undivided India and later independent Bangladesh. This article has two key arguments; firstly, political recognition of a religion(s) or preferential treatment of any religious group has never had a positive impact upon the countries Indian sub-continent (which includes Bangladesh). Secondly, based on the streamline of the first argument, the article further argues that since the preferential treatment of religion has repeatedly given rise to negative consequences, it is highly probable that declaring Islam as the state religion under the state religion clause is not advisable in the context of the secular constitutional framework and likewise, will work against, rather than encouraging, religious harmony.
\end{abstract}

\section{Introduction}

The period between the late $19^{\text {th }}$ to mid- $20^{\text {th }}$ centuries was the turning point in the Indian subcontinent $^{1}$ as this was the time when the people of the Undivided India ${ }^{2}$ started to revolt against the British; demanding equal rights and equal participation in the governance of India. Historical narratives demonstrate that these uprisings had eventually paved the way to

\footnotetext{
${ }_{2}^{1}$ It includes Indian, Pakistan, and Bangladesh.

2 Before the creation of India and Pakistan as a separate in 1947, India was known as the Akhand Bharat or the undivided India.
} 
decolonization and the creation of two independent states, India and Pakistan. This freedom, however, came at a great price. This period is remembered as a time of widespread communal violence leading to, perhaps for the first time, perpetual animosity between Hindu and Muslims communities sharing the Indian subcontinent. Historical accounts show that this animosity was triggered when religion was brought into politics by political parties and when the British colonizers opted out the infamous 'Divide and Rule' policy by giving preferential treatment to a particular religious groups in different laws (e.g. the Government of India Act 1919 and Government of India Act 1935) and administrative policy (e.g. during the territorial partition of the Bengal province). This religion-based politics eventually led to a chain of continuous and unprecedented events.

Against this backdrop, this article, by drawing from historical narratives (from 1900$2011^{3}$ ), will show that political recognition of a religion(s) or preferential treatment of any religious group has never had a positive impact upon the Indian sub-continent. This article will also argue that giving political recognition to a particular religion(s) by the state (e.g. declaring Islam as the state religion in the constitution) is not conducive for the secular constitutional framework and does not maintain religious harmony.

The article divides its discussion into three parts: part I explores the historical events (1900-1947) to show how religious harmony between different religious communities was dismantled because colonizers and political parties used religion to gain political advantage, which in turn created perpetual animosity between Hindu and Muslims and finally caused the division of India. Following that, part II discusses how the West Pakistani rulers' attempt to

\footnotetext{
${ }^{3}$ The reader should keep in mind that the some of the historical events (from 1900-1971) discussed in this article predated independent Bangladesh, but as the territory that constitutes present Bangladesh was part of India before 1947 and Pakistan before 1971, these historical accounts are very much part of the history of Bangladesh.
} 
build an Islamic state through constitutional means by denying the secular linguistic identity of the East Pakistani (now Bangladesh), triggered the liberation war in 1971, eventually leading to the liberation of Bangladesh. Finally, part III focuses on the Bangladesh era and shows how the introduction of pro-religious policies weakened the pro-secular constitution framework designed and implemented in the first Constitution. This part also shows how the pro-secular constitutional framework was gradually Islamized, making Bangladesh an insecure place for religious minorities.

Although this article will not directly address the issue of the compatibility of the state religion clause with secularism in the Constitution of Bangladesh, it will clarify why recognition of religion in the constitution is particularly harmful to Bangladesh by going through each historical turning point before the parliament juxtaposed secularism and the state religion in the constitution in 2011.

\section{PART I: FROM RELIGIOUS HARMONY TO ANIMOSITY BETWEEN MUSLIM AND HINDU COMMUNITIES OF THE UNDIVIDED INDIA}

The current socio-political factors and events ${ }^{4}$ that are related to religion and secularism in Bangladesh cannot be fully comprehended without first exploring the pre-liberation history of Bangladesh in connection with the numerous roles of religion (e.g. shaping public life and political trajectory, influencing legal and policy framework and principal catalyst of communal animosity between Hindus and Muslims). To that end, the following discussion will explore the key historical events of the pre-Bangladesh era.

\footnotetext{
${ }^{4}$ The following factors and events influenced hundred years of history, namely: the detrimental effect of religion in public life, the bitter relationship between two predominant religious communities, i.e. Hindus and Muslims, the catalyst behind the systematic religious violence and the reason for adopting secularism (in Muslim majority country) as a fundamental principle in the original Constitution of Bangladesh (in 1972).
} 


\section{A. The Era of Religious Harmony (8th Century to 18th Century AD)}

It is difficult to pinpoint the exact point of departure; nevertheless, religion became a significant catalyst in South Asia when the Arab Muslim traders entered South India in the $8^{\text {th }}$ Century. ${ }^{5}$ Although these traders were not part of any missionary group, they did play some role in converting people of different faiths (mostly Hindus) to Islam. Nevertheless, the degree of conversion was not noticeable enough to trigger the wrath of the Hindu Kings. ${ }^{6}$ In fact, history shows that, even with the issue of proselytization, the people of both communities (i.e. Hindus and Muslims) were living side by side in tranquility. ${ }^{7}$ Later, during the time of Muslim rule in India, the most of the Muslim rulers were tolerant and forced proselytizing of the people of Hindu communities was not a common phenomenon. ${ }^{8}$ However, some historians argue that there was a record of mass conversion of lower caste Hindu to Muslims ${ }^{9}$, but most of the conversions were a self-defense strategy initiated by the people of the lower Hindu caste to escape oppression by higher castes. ${ }^{10}$

The reason most of these rulers opted for tolerance and persuasion, in contrast to forcing conversion was that they realized that any policy against the common people or their religions would cause massive discontent and would threaten their reign. For instance, during the time of Empire Akbar, the Hindus controlled some of the key administrative positions of the regime and many Hindu kings continued their reign under his command. Therefore, religious differences did not constrain peaceful cohabitation. There were not any significant historical records of

\footnotetext{
${ }^{5}$ Ram Gopal, Indian Muslims: A Political History (1858-1947), (Asia Publishing House, 1959) 1.

${ }^{6}$ ibid.

${ }^{7}$ ibid.

8 See generally, ibid at 5-12.

${ }^{9}$ See, Kenneth J Saunders (ed), A pageant of Asia; a study of three civilizations (Oxford University Press, H. Milford, 1934) 162; see also, Roland E Miller, Mappila Muslims of Kerala: a study in Islamic trend, (Orient Longman, 1992) 93.

${ }^{10}$ See, Abdul Halim, Legal System of Bangladesh, (CCB Foundation).
} 
communal discontent or violence during the reign of Hindu and Muslim rulers. ${ }^{11}$ Therefore, communal animosity was not presented before the British made India its colony in $1863 .^{12}$

The reason that the British colonial period was considered to be the point of departure for communal animosity is that centuries of religious harmony were undermined and religious identity became more important than the common interest. The historical sources depict how communal elements were used by the British administration to discourage unity amongst the natives of the territory.

While it is difficult to pinpoint the exact events that made the British realize the advantage of communal elements, the use of communal sentiment was found be a great tool for the British during the Sepoy Mutiny in 1857 (known as Sepoy Bidraha in Bengali). Historical records show that the reason for the mutiny was based on an allegation against the British that the ammunition for a new rifle that used paper cartridges that came 'pre-greased' required soldiers to bite the cartridge open to release the powder, ${ }^{13}$ which was made of tallow derived from beef and pork, prohibited by dietary law for Hindus and Muslims. ${ }^{14}$ This allegation angered both the Hindus and Muslims soldier of the British army and they revolted to overthrow the British. Although both Hindus and Muslims participated in the mutiny, the motive for doing so was to protect their religion from one another. This event was pivotal for the British administration, as the later discussion will show that the British started using the communal element to validate their policies and create division between religious communities (especially Hindus and Muslims).

\footnotetext{
${ }^{11}$ Ahmed Sarif, Sampradayekatar O Samayer Nana Katha), (Agamee Prakashani, 2015) 10.

12 ibid at 23.

${ }^{13}$ Daniel R Headrick, The Tools of Empire: Technology and European Imperialism in the Nineteenth Century, (Oxford University Press, 1981) 88.

14 ibid.
} 


\section{B. Harmony Dismantled- Negative Impacts of Use of Religion in Politics and Public Affairs}

\section{(From 1905 to 1947)}

One of the first instances of the British applying the use of communal elements, as triggered by the 1857 Mutiny was when the administration faced widespread opposition from Indians (Hindu and Muslim) against its decision to re-demarcate the province of Bengal (popularly known as the partition of Bengal). The following discussion will discuss events related to partition and explain how this event marked the beginning of the infiltration of communal policies in public affairs and politics.

\section{a. Partition of Territory of Bengal in 1905 Based on Religious Proportionality and Its}

\section{Effects}

From the British perspective, the partition of Bengal territory was a policy decision of administrative convenience, ${ }^{15}$ but it had political implications as well. The political reason behind the partition became apparent in 1903, when Lieutenant Governor AHL Fraser advised Governor General Lord Curzon that Dacca and Mymensingh districts should be separated from Bengal, because they were "the hotbed of the purely Bengali movement, unfriendly if not seditious in character, and dominating the whole tone of Bengali administration". ${ }^{16}$ In response to that recommendation, Lord Curzon decided to divide Bengal. His original scheme for partition

\footnotetext{
15 According to the British government, the principal motive for the partition was that of administrative convenience. Bengal, with a population of seventy-eight million and an area of 189,000 square miles (Bihar, Chota Nagpur, and Orissa being included in it) was too large a province to be efficiently administered, see, Anil Baran Ray, 'Communal Attitudes to British Policy: The Case of the Partition of Bengal 1905' (1977) 6(5) Social Scientist 34,34 . 16 ibid.
} 
was published in the Gazette of India on December 12, 1903. ${ }^{17}$ However, this decision aroused massive discontent from Hindu and Muslim community of Bengal on different grounds. ${ }^{18}$

Hindus and Muslims alike rejected Lord Curzon's initiative, and he had to face hundreds of protest meetings where both communities participated. ${ }^{19}$ Curzon anticipated that the scheme would meet with opposition, particularly from the Hindus of Bengal. ${ }^{20}$ Therefore, to subdue the uprising and dismantle communal unity, Curzon decided to promote the Muslim community, who were minorities in the undivided Bengal. The reason was that, since 1763, the Muslims had been a backward community with little influence in administration and politics. It was therefore advantageous for Curzon to use communal elements to incite them against the Hindu leaders, who occupied the major positions in mainstream politics. Consequently, Curzon decided to change the balance of interests favoring Hindus and constructed the partition in a manner that appeared to be beneficial to the Muslims of Bengal. ${ }^{21}$ However, the Hindus vehemently opposed this later scheme. The Hindu leaders were also willing to bargain the annulment of the partition at the expense of Muslim interests. The anti-partition movement thus gradually became more and more pro-religious and less of a national movement. This strategic use of religious/communal elements became more frequent over time, eventually creating a rift between the Hindus and Muslims of undivided India.

\footnotetext{
17 ibid, 35 .

${ }^{18}$ The following are some of the main grounds: (i) suspicion of divide and rule strategy; (ii) the Hindu leader (mostly were also landlords) from Eastern Bengal feared that their authority over the province would be prejudiced; (iii) the Hindu leader from western part fear that the significance of Calcutta (then capital of India) as political and economic center point will be diminished; (iv) the Muslims of the Eastern part of Bengal feared that the government wanted to turn them into Assamese (people of Assam); (v) Hindu Intellectual saw this as an attack against their pride, sentiment and self-esteem and attempt to dismantle inseparable cultural and linguistic bond, see Ray (n 15) 36, 39, M R A Baig, 'The Partition of Bengal and Its Aftermath' (1969) 30(2) Indian Journal of Political Science 103, 111, A K Biswas, 'Paradox of Anti-Partition Agitation and Swadeshi Movement in Bengal (1905)' (1995) 23(4/6) Social Scientist 38, 39.

${ }^{19}$ Gopal (n 5) 91.

${ }^{20}$ Ray (n 15) 35.

${ }^{21}$ Gopal (n 5) 91.
} 
In a nutshell, this section showed how centuries of religious harmony began to crumble when the religious element was introduced to state affairs. This also indicates that people from different religious communities lived in harmony and peace as long as their religion was undisturbed.

The following section will further this discussion by showing how religion was used in political movements and legal policy to forge perpetual division and animosity between Hindus and Muslims of the undivided India, and would lead to the creation of a separate India and Pakistan on the basis of religion.

\section{Negative Implications of the Use of Religion in Political Movements and Legal Instruments (From 1905 to 1947)}

While the British can be held primarily responsible for igniting the communal flame, it would be wrong to claim that the British played 'the only role' in creating a division between the communities. The leaders of Muslims and Hindu communities played an even greater role in exploiting the emotions of the masses. It can be seen by a scrutiny of anti-British movements between 1905-1947 which reveals that leaders of both communities used the communal element to gain popular support. For instance, the popular nationalist Movement known as the Swadeshi movement, which aimed at the partition of Bengal, was one of the earliest examples in which communal harmony broke down because of the introduction of religious elements by the Hindu leaders. The boycott was initiated by a resolution that people of Bengal will abstain from purchasing British manufactured goods, their education, and employment as a means to create 
economic pressure on the Government. ${ }^{22}$ However, this national movement became pro-religious in the hand of the leaders of the Swadeshi movement, who were mostly Hindu leaders based in Calcutta, and because the most prominent supporters were members of the Indian National Congress (INC), (the most dominant political party with majority Hindu members).

This shift in attitudes and its impact on Muslims has been well depicted by Surendranath Banerjee, a Hindu leader of the anti-partition movement who wrote in his autobiography: "Swadeshi had evoked the fervour of a religious movement. It has become part of our Dharma. Naturally, the Muslims could not be expected to subscribe to something which had become a part of the Hindu Dharma $[\ldots]$ the Swadeshi vow to a Hindu audience in the presence of the god of their worship. Such incidents and the use of Hindu symbols to identify nationalism could not but be offensive to the Muslims". 23

The Swadeshi movement, despite starting as a united and secular movement, eventually turned into a religiously motivated one. This shows that Hindu leaders sacrificed their Muslim comrades for the sake of achieving their objectives against the British and to introduce a religious element to motivate their movement knowing that this would force the Muslims out of any possible future movement. This communal attitude of the Hindu leaders changed the future of political trajectory, as Muslims came to realize that Hindu leaders could not protect their interests.

This suspicion and distrust between the communities gave rise to a fear of Hindu dominance over Muslims. Therefore, Muslim leaders thought of establishing their separate political identity (against INC that apparently became a pro-Hindu platform) to ensure the benefits of the Muslim

\footnotetext{
${ }^{22}$ See generally, A. K. Biswas, 'Paradox of Anti-Partition Agitation and Swadeshi Movement in Bengal (1905)' (1995) 23(4/6) Social Scientist 38.

${ }^{23}$ Ray (n 15) 44.
} 
community. The following sections will highlight how this political transition caused social disorder and disintegration in the undivided India.

\section{a. Creation of the Separate Political Entity Based on Religious Identity and Its}

\section{Impact}

The All-India Muslim League (AIML) was formed in 1906 by the covert influence of the British administration and under the auspicious of $\mathrm{Nawab}^{24}$ of Dacca (now Dhaka: the capital of Bangladesh) to support the partition movement, adopting the same communal approach as the Hindu leaders. ${ }^{25}$ This unlikely union with the colonial powers was no coincidence; rather it was a result of a compromise reached through the Simla Pact in 1906, where the Muslims leaders were assured by the British that they would get preferential treatment and benefits. One such benefit was separate reserved seats in the provincial legislative assembly for the Muslims, irrespective of the proportion of the Muslims in the general population. ${ }^{26}$ Later, the Indian Council Act of 1909 also provided provisions for a separate electorate based on religious identity in the (Imperial Legislative) Council. ${ }^{27}$ However, the Hindus leaders of INC opposed this special preference because it was seen as the starting point of the transformation of India into 'Muslim India'. Therefore, Hindu leaders increased the level of anti-partition movement, and this resistance was overwhelming for the British. As such, despite efforts to this end, the Muslim League failed to retain partition, and the partition of Bengal was annulled in 1911. However, the decision turned out to ultimately be beneficial for the British as it allowed it on the one hand to formally end the

\footnotetext{
${ }^{24}$ During the time of British India, the title of "Nawab" was a personal distinction awarded by the British government to persons and families who either ruled a princely state or had done various services to the Government of the British India. This system is identical to a British peerage.

${ }^{25}$ Ray (n 15) 44.

${ }^{26}$ See, K C Chaudhry, Role of Religion in Indian Politics (1900-1925), (Sundeep Prakashan, 1978) 167.

${ }^{27}$ ibid, 179.
} 
possibility of harmony between these communities (Hindu and Muslim) by showing that Muslims could never properly establish their interests under Hindu domain and, on the other hand, to remain neutral and faultless in the eyes of both religious parties.

In sum, the partition of Bengal was one of the first instances of the use of religion in politics or public policy. It caused a serious anomaly in society as it manipulated the psyche of the people, causing serious social disorder and disintegration of harmony. The following discussion will address another dimension to cases where the use of religion has caused the above negative consequences.

\section{b. Preferential Treatment on Religious Grounds through Constitutional Documents and resulting Negativity (From 1919 to 1947)}

In addition to the use of religion in administrative policy and political movements, religion became a catalyst for the formation of legal frameworks. For instance, the Government of India Acts of 1919 and 1935 (the Acts) (considered to be the most important constitutional documents enacted by the British Government as the process of initiating democratization in India $)^{28}$ proposed special preferential representation of the Muslim and Sikh communities through the provision of separate electorates for these minorities. However, this preferential treatment was discouraged in the Mont-Ford Report based on which the Act of 1919 was passed. As per that report, "the communal electorate was opposed to the teaching of history and perpetuated class divisions and stereotyped existing relations". ${ }^{29}$

\footnotetext{
${ }^{28}$ Ian Talbot \& Gurharpal Singh, The Partition of India, (Cambridge University Press, 2009) 32.

${ }^{29}$ Chaudhry (n 26) 218.
} 
The Act of 1919 was welcomed by the Muslim leaders and rejected by the INC. The INC doubted that the scheme would ensure their claim for home rule. The separate electorate system was also criticized as being impractical, although it was initially supported by the INC in the Lucknow Pact. ${ }^{30}$ Since the INC was a political force not to be ignored, the Act of 1919 was not enforced. Eventually, a new Government of India Act was propounded in 1935, which accommodated INC political objectives. This later Act introduced substantial measures of representative government through provincial autonomy (e.g. for the first time, law and order became subject to home rule instead of the British government). ${ }^{31}$ The Act also kept the mechanism of the controversial separate electorates, though not in terms of AIML, which demanded 50 percent representation, and under this Act, the first election was conducted in 1937.

The Act was a major step towards the democratization of India, but it did not bring the results that its drafters expected. Rather, the new Act paved the way for INC dominance. This was because, by having a separate electorate for the Muslims, their representation was isolated within the Muslim community. It therefore reduced the Muslim community's chance to become a parallel political power in India (to Hindus). Furthermore, the newly formed Congress Government failed to fulfil their election manifesto which focused on the economic and social concern of the masses as opposed to communal issues. ${ }^{32}$ The reason for this failure was the effect of post-election activities of INC that made the Muslims suspicious about Congress' strategies when the INC offered a share in governing power to the Muslim League in the UP in exchange

\footnotetext{
${ }^{30}$ See for details ibid, 210.

${ }^{31}$ Talbot, (n 28) 32.

32 ibid.
} 
for renouncing their pro-Islamic political ideology. ${ }^{33}$ The AIML leaders considered this to be a forced assimilation of their interest within the domain of Congress' pro-Hindu interest. It became even more apparent when the new administration started adopting pro-Hindu policies like cow protection (sacred to the Hindus, but permissible food for Muslims) and the promotion of Hindi language and other religious symbolism. ${ }^{34}$

To conclude, it is irrefutable that the use of religious markers, a pro-religious approach in formulating constitutional documents, Congress' communal attitude and the sense of distrust of the Muslim leader on INC strategies, gave the final impetus to the AIML to forward the demand for a separate state, i.e. Pakistan, under the two-nation theory. The following discussion will show how the idea of two nations was originated and how the impossible division of territory was made based on the religious marker.

\section{c. Peculiar Construction of the Idea of Two-Nations based on a Religious Marker}

The partition of the undivided India into India and Pakistan in 1947 by the British based on the religious marker can be said to be an unrealistic and overly-simple division. This is because, in making the division, the distinct and complex socio-cultural-political factors that existed at a national and regional level in pre-partitioned India were not properly considered by the British. These socio-cultural-political factors were related to the version of nationalism that had been propagated by the two prevailing political powers - INC and AIML - before partition. It is evident from partition historiography that, while the INC tried to promote a kind of secular based nationalism (though this secularized version was later given a religious color), the AIML

\footnotetext{
${ }^{33}$ ibid.

${ }^{34}$ ibid, 32-33.
} 
propagated a pure communal nationalism based on Muslim identity. ${ }^{35}$ However, the factor that both these parties failed to recognize was that at the regional level, such as the Eastern part of Bengal and Punjab, the constitutive elements of nationalism were not purely religious, but also comprised other unique ethnolinguistic features. ${ }^{36}$

In this context, one may question why the regional leaders from the Eastern part of Bengal concurred with an AIML policy for a separate state for Muslims. The reason was that they chose the best of a bad set of options, i.e. liberation from colonial power while avoiding any possibility of supporting Hindu dominance. This was the strategy used by the AIML, particularly by Muhammad Ali Jinnah (an AIML leader of who became sole spokesperson for the Muslim community during the 1920 s), who demanded the separate nation ${ }^{37}$ to emancipate the Muslim community from Hindu dominion. ${ }^{38}$ Therefore, the bone of contention was not strictly religious grounds (e.g. force conversion and/or preventing the observation of religious practice) because there was no apparent threat to the religion. Rather, it was the potential fear of continued dominant-subordinate relations in any future shared state. Therefore, religion was used initially by the British as a dominating mechanism and then later by the Indians themselves as the spiritual foundation of independence. It eventually established a binary ideology between the communities and a contest for separate dominance. ${ }^{39}$

This shows that the partition of India was in fact a political game, rather than a crusade to establish a theocracy. The socio-cultural plurality of this region made it impractical, if not

\footnotetext{
35 See generally, Sana Aiyar, 'Fazlul Huq, Region and Religion in Bengal: The Forgotten Alternative of 1940-43' (2008) 42(6) Modern Asian Studies 1213.

36 Zillur R Khan, 'Islam and Bengali Nationalism' (1985) 25(8) Asian Survey 834, 834.

37 This idea of Jinnah later known as the "Two-Nation Theory" based on religious identity, which was applied by the British to divided India in 1947.

${ }^{38}$ See, "Mr. Jinnah's Presidential Address to the Constituent Assembly of Pakistan (August 11, 1947)", online: $<$ www.pakistani.org/pakistan/legislation/constituent_address_11aug1947.html>.

${ }^{39}$ Satish Saberwal, 'The Partition: Communalization, Contestation, and Interaction?' in Kaushik Roy (ed), Partition of India: Why 47? (Oxford University Press, 2012) 35, 42.
} 
impossible, to form either a purely theocratic state or a purely secular state (like French laicite ${ }^{40}$ ). The post 1947 era of Indian history proves this: one, a successful union of India (which based the policy to establish a secular state with the protection of religious plurality) and two, an unsuccessful Federation of Pakistan which tried to establish a theocratic state by inserting religion into the constitution and governance policy, thereby disregarding the cultural and regional diversity of the people of West Pakistan (East Bengal became part of Pakistan after 1947). Therefore, the use of religious marker, while providing a good foundation for political agitation toward the claim for a separate state, was not a practical formula for building a future stable social order. This became apparent after the separation of undivided India in 1947.

The following discussion will explore the separation of India and show how the idea of building two separate nations for Hindu and Muslims proved to be an impractical one.

\section{d. Partition of India and Pakistan in 1947 Based on a Complex Religious Marker}

The decolonization of India was inevitable given the massive pro-independence movement initiated by the INC and claims of a separate state from the AIML. However, the key issue for the British was how India would become independent. The British and Gandhi initiated some efforts to avoid the partition of India. However, by mid-1940, communal politics had become so predominant that all possibilities of integration were effectively excluded. Therefore, the creation of two religiously-based nations was the only real option left before to the British.

\footnotetext{
${ }^{40}$ The French model of secularism which is known as laicïté reduces the public influence of religion by prohibiting all forms of religious symbols or dresses that may create differences among citizens, see, Ahmet T Kuru, Secularism and state Policies Toward Religion: The United States, France, and Turkey, (Cambridge University Press, 2009) 124.
} 
As per this formula, Cyril Radcliffe ${ }^{41}$ divided the territory into the territories of India and Pakistan, where India got the lion's share of the territory because Hindus were the major inhabitants of undivided India and Pakistan got two discrete territories (West Pakistan and East Bengal, later know as East Pakistan), which were separated from each other by about $1500 \mathrm{~km}$ and India between them. ${ }^{42}$ Therefore, Jinnah's political strategy was founded on the aspiration of the emancipation of Muslims from Hindu domain remained unrealized and the "minority syndrome" became even more concentrated and acute. ${ }^{43}$ Moreover, the partition could not resolve these problems because, when border lines were drawn between two states, the formula was purely scientific, not taking into account the regional, ethnic, linguistic, cultural, social diversity. This failure eventually gave rise to more insatiability and violence in the independent India and Pakistan. ${ }^{44}$

Pakistan arguably faced even more of a challenge than India because the whole idea of Pakistan was misconceived. The reason is that, when Choudhary Rahmat $\mathrm{Ali}^{45}$ first proposed a separate homeland for the Muslims, the idea of Pakistan had not yet been coined. In other words, what Jinnah (as spokesperson for the Muslim community and the AIML) was offering was emancipation from the Hindu domain, because Hindus and Muslims were irreconcilably opposed to a monolithic religious community and there was no possible way to coexist peacefully. Thus, religion once again was used to attract the Muslims, though the motive of Jinnah was not to

${ }^{41}$ Cyril Radcliffe was a UK lawyer with impeccable service record who was the Chairman of Boundary Commission. He was entrusted with the extreme task of drawing a boundary between into a territory that had been integrated for thousands of year in only five weeks (from July 8-August 17, 1947).

${ }^{42}$ Willem Van Schendel, A History of Bangladesh, (Cambridge University Press, 2009$) 107$.

${ }_{43}^{43}$ Jaswant Singh, Jinnah: India-Partition-Independence, (Rupa \& Co., 2009) 489.

44 The scenario of post-partition social disorder e.g. massive exodus, communal riot, forced deportation, expropriating property have in detail discussed in literature related to the partition of India and Pakistan, as such, this article within its limited scope will not repeat this discussion in depth.

${ }^{45} \mathrm{He}$ is the "Founder of Pakistan National Movement," in which the word "Pakistan" appears to have been used for the first time in a document, See, G Allana, Pakistan Movement Historical Documents, (Department of International Relations, 1969)103-110. 
establish an Islamic state. ${ }^{46}$ For this reason, when the AIML's representatives gathered in Lahore in 1940 for their annual session, the resolution (the Lahore Resolution) ${ }^{47}$ proposed the autonomous establishment of sovereign 'states' in the North-East and North-West, where Muslims were the majority. ${ }^{48}$ However, as Talbot and Singh observe, the vagueness of the scheme gave Jinnah room for maneuvering towards resolution and subsequently the term 'state' was introduced to the idea of a 'Muslim state'. ${ }^{49}$ This was how the idea of Pakistan was conceived. This dramatic shift was political and utilitarian because within the scheme of 'separate states', the AIML and Jinnah would not become the sole dominant powers. Therefore, it was necessary to propound the 'Two-Nation Theory', which proposed a separate country for Muslims alongside Hindus. However, Jinnah's scheme failed to be executed because of the mix of people of different religions in all provinces of undivided India. ${ }^{50}$ Pakistan therefore turned out to be a separate but 'not a single' state. There were socio-cultural differences in the regions that became the two wings of Pakistan in 1947. These differences subsequently created differences of opinion between provinces, especially affecting the Eastern Province, which later seceded from Pakistan in 1971 to become Bangladesh.

The following part will explore the key reason for this conflict and eventual secession. In this connection, it will show how the forced imposition of Islam in public affairs by denying the secular identity of the East Pakistan (now Bangladesh) had played a vital role in the secession of 1971 and the creation of Bangladesh.

\footnotetext{
${ }^{46}$ See, (n 49).

${ }^{47}$ See, "Presidential address by Muhammad Ali Jinnah to the Muslim League Lahore, 1940", online: <www.columbia.edu/itc/mealac/pritchett/00islamlinks/txt_jinnah_lahore_1940.html >.

${ }^{48}$ Talbot (n 28) 33.

49 ibid, 33.

${ }^{50}$ See, "Move to Partition Punjab AND Bengal: Text of Mr. Jinnah's Statement", online: <www.nationalarchives.gov.uk/wp-content/uploads/2014/03/fo371-635331.jpg>.
} 


\section{PART II: THE CREATION OF PAKISTAN BASED ON RELIGION AND THE} AFTERMATH (From 1947-1971)

\section{A. The Journey of 'Moth-Eaten' ${ }^{51}$ and Conflict Trodden Pakistan}

After the creation of Pakistan, "Jinnah got the land but failed to create a state; and failed so decisively in crafting a nation". 52 The reason is that some form of territorial or cultural cohesion was required to forge a national identity. For Pakistan, religion was the only common factor between both territory and culture, which in itself was not strong enough to forge a common bond. A central part of Islam relates to one's relationship with $\operatorname{God}^{53}$, and it does not have a common institutional attachment like the Christian church. The only near equivalent of the Church, the Caliphate, had expired in 1919 with the advent of Kemal Ataturk's regime. Therefore, other factors, e.g. linguistic, ethnic, sub-national, provincial and ideological, gradually emerged to become constitutive of national identity in Pakistan. ${ }^{54}$ This in turn created the first fissure between pro- Islam-West Pakistan and pro- secular East Pakistan.

\section{a. Conflict between East and West Pakistan: Religious Identity versus Linguistic-}

\section{Cultural Identity}

Through the creation of Pakistan in 1947, Jinnah, having left with some territories and imagined homeland, made a new start regarding his political strategy. In his first address to the

\footnotetext{
${ }^{51}$ The "Moth Eaten" metaphor had become inseparable with Pakistan since the partition of 1947. The origin of this metaphor is unknown, though; it was initially used by the anti-partition advocates who strongly believed the idea of Pakistan could never be successful due to the inseparable Geo-cultural characteristics of erstwhile-undivided India.

52 Singh (n 43) 515.

${ }^{53}$ H Patrick Glenn, Legal Traditions of the World: Sustainable Diversity in Law, (Oxford University Press, $4^{\text {th }}$ ed, 2010) 191.

54 Nighat Said Khan, 'The Global Order: Politics and the Women's Movement in Pakistan' in Soofia Mumtaz et el (eds), Pakistan: The Contours of state and Society, (Oxford University Press, 2002) 137, 139.
} 
constituent assembly of Pakistan as the first Governor General, he showed a clear inclination towards secular governance policy. To quote Jinnah:

If you will work in co-operation forgetting the past, burying the hatchet, you are bound to succeed [...] We should begin to work in that spirit, and in course of time all these angularities of the majority and minority communities, the Hindu community and the Muslim [...] will vanish [...] You are free; you are free to go to your temples, you are free to go to your mosques or to any other place or worship in this state of Pakistan. You may belong to any religion or caste or creed -- that has nothing to do with the business of the state [...] We are starting with this fundamental principle: that we are all citizens, and equal citizens, of one state. ${ }^{55}$

Jinnah realized that state unity could only be ensured if the state remained neutral as to religion, and respected pluralistic identities. Therefore, he argued that it was imperative for the Constituent Assembly of Pakistan to formulate a constitution that would recognize the principle of secularism as a governing principle.

However, Jinnah himself derogated from his path when he denied any official recognition to Bengali (the language of the majority of people of East Pakistan) to declare Urdu as the only state language of Pakistan. ${ }^{56}$ The preference for Urdu was its connection with Arabic and Farsi (both languages having rich Islamic literary resources). Hence, this move was seen as the identity of Indian Muslims and their culture. ${ }^{57}$ However, as this decision constituted a direct denial of the linguistic identity of the people of East, it created enormous national tensions. Added to this debate was the fact that Urdu was only used by 3 percent of the total population, thus falling

\footnotetext{
55 "Mr. Jinnah's address to the Constituent Assembly of Pakistan", online: $<$ www.columbia.edu/itc/mealac/pritchett/00islamlinks/txt_jinnah_assembly_1947.html $>$.

${ }^{56}$ Van Schendel (n 42) 111.

57 Philip Oldenburg, 'A Place Insufficiently Imagined": Language, Belief, and the Pakistan Crisis of 1971' (1985) 44(4) the Journal of Asian Studies 711, 717.
} 
behind dozens of other languages, amongst which Bengali was the first, with 56 percent usage. ${ }^{58}$ Religious implications were again uncritically brought into public discourse by promoting the case for the assumed connection between the Bengali language and Hindu heritage (the religious text of Hinduism is written in the Sanskrit language from which the Bengali language originated).${ }^{59}$ Therefore, Bengali was branded as the language of the Hindus and the Bangalee Muslims became half-Muslims. This communal attitude was the source of the animosity between East and West Pakistan.

Critiques may question why the West Pakistani government repeated the British mistake of using religion as a public affairs strategy. In this regard, Professor Ali Riaz observed that the language issue became a crucial factor due to its connection with the feudal foreign elements, i.e. Zamindars (landlords) who controlled the economic resources of Pakistan. ${ }^{60}$ Urdu was esteemed by those feudal powers as a symbol of aristocracy ${ }^{61}$ Therefore, it was necessary for West Pakistan to placate the interests of the aristocracy in order to secure their power.

Thus, once again, religion was used not to protect religion itself, but rather was used to protect the interests clearly superficial to Islam. This pro-Islam attitude continued, despite growing discontent in the Eastern Part. The following part will discuss the scheme of the West Pakistani ruler in forcibly building an Islamic state, which aggravated the relation between two provinces.

\section{B. The Efforts to Build a Theocratic Constitution and the Aftermath}

The discontent over linguistic identity was not the only factor that compelled East Pakistan towards secession in 1971. The East Pakistanis were subjected to colossal economic deprivation

\footnotetext{
${ }^{58}$ Van Schendel (n 42) 110.

${ }^{59}$ Oldenburg (n 57) 724-725.

${ }^{60}$ Ali Riaz, Unfolding state: The Transformation of Bangladesh, (de Sitter Publications, 2005) 58.

${ }^{61}$ Ibid.
} 
and were neglected by both civil and military administration. ${ }^{62}$ The double standard in terms of treatment of Pakistanis from the East and West was first a result of racism (since Bangalees were still assimilated with Hindus), and second, a tool to protect the interest of AIML leaders who primarily originated from the West. Therefore, the national policies of Pakistan became Westoriented. In the absence of any other commonality, the hegemonic use of Islamic identity appeared to be the best strategy to create the national bond. This is evident from the speech of Jinnah made in Dacca of East Pakistan:

[h]ave you forgotten the lesson that was taught to us thirteen hundred years ago? Who were the original inhabitants of Bengal-not those who are now living. So, what is the use of saying 'we are Bengalis, Sindhis, or Pathans, or Punjabi'. No, we are Muslims. Islam has taught us this, and I think you will agree with me that whatever else you may be and whatever you are, you are Muslim. ${ }^{63}$

Jinnah made it clear that Pakistan would continue with the Islamization by intentionally bringing communal idioms to justify his actions, while neglecting all other factors necessary for cohesion between East and West. Subsequently, West Pakistan targeted the constitution as the means to forge a common Pakistani nationalism, which again was based on Islam. The first such attempt was made in the 1956 Constitution, which had provided for a complete structure for a theocratic state. The significant theocratic features of this constitution were: firstly, that Pakistan be recognized as an Islamic Republic; secondly, that the constitution be guided by the principles of democracy, freedom, equality, tolerance, and social justice as enunciated by Islam; thirdly, that the head of the state had to be a Muslim; and fourthly, a repugnancy clause which is related

\footnotetext{
${ }^{62}$ Van Schendel (n 42)108.

${ }^{63}$ Ashok Kapur, Pakistan in Crisis, (Routledge, 2006) 22.
} 
to giving primacy to Sharia law over other laws if the Supreme Court of Pakistan finds a direct conflict with the Holy Quran. ${ }^{64}$

The constitutional provisions for 'non-Muslims' (note: not minorities), transformed nonMuslims to second-class citizens due to dominating theocratic features. Moreover, East Pakistani Muslims became victimized because they were forced to accept this neo-nationalism which was against their cultural diversity and linguistic identity. ${ }^{65}$ It became a source of tension because, although as Muslims they supported Pakistan, ${ }^{66}$ they never vouched for theocracy. This polarized position of the provinces made the situation graver. West Pakistan subsequently made some efforts to break the ice and tried to reconcile the issue related to identity in the constitution. For instance, General Ayyub Khan, who assumed power in Pakistan by a coup d'état on 7 October 1957, tried to legitimize his rule and gain popular support by introducing a new constitution in 1962 which reduced the theocratic features of the earlier constitution. The 1962 Constitution, while based on its predecessor constitution, omitted many references to Islam, including changing the official name into the Republic of Pakistan (omitting 'Islamic'). However, Ayyub had to reverse these constitutional changes because of constant pressure from the Islamist group Jamat-i-Islam who condemned Ayyub for derogating from Islam. ${ }^{67}$ In his efforts to appease the Islamists, Ayyub failed to stabilize political upheavals in both East and West Pakistan. In particular, the Awami League ${ }^{68}$ (AL) under the leadership of Sheikh Mujibur Rahman

\footnotetext{
${ }^{64}$ Martin Lau, 'Islam and the Constitutional Foundations of Pakistan' in Rainer Grote \& Tilmann J Röder (eds), Constitutionalism in Islamic Countries: Between Upheaval and Continuity, (Oxford University Press, 2012) 171, 192-195.

${ }^{65}$ Jnanbrata Bhattacharyya, 'Aspects of Cultural Policy in Bangladesh' (1983) 18(13) Economic and Political Weekly 499, 501.

${ }^{66}$ Oldenburg (n 57) 712.

${ }^{67} \mathrm{Lau}(\mathrm{n} 64) 194$.

${ }^{68}$ The Awami League was the leading political parties of the erstwhile East Pakistan who played the pivotal role in protesting the Martial law rule in the Pakistan. In 1970, it secured the landslide majority in the Election but was refused by the Martial Law ruler to form a government. Later when Pakistan's occupation begun in 1971, AL played
} 
(hereinafter referred as Mujib), who by 1969 had become the popular leader in East Pakistan launched a fully-fledged movement for regional autonomy against Ayyub's non-political authoritarianism. Amidst these political upheavals, Ayyub resigned, and power was taken by General Yahya Khan on 25 March $1969 .{ }^{69}$ Yahya tried to stabilize the situation by handing power to political parties through elections. The 1970 national election proved a turning point with AL winning 167 seats of 169 to form a central Government. ${ }^{70}$ However, this outcome was not welcomed by the winner in the West, the Pakistan People's Party (PPP) (under the leadership of Zulfiqar Ali Bhutto). Under pressure by the PPP, the National Assembly began to frame a new constitution, although this process was indefinitely postponed on $3^{\text {rd }}$ March 1971 by Yahya. ${ }^{71}$ This outcome was the final turning point in the history of undivided Pakistan.

These historical accounts show that the main reason for denying the Eastern part the right to form a government was the West's perception of East Pakistan's culture as an offshoot of Indian Hinduism. The ability of East Pakistan to form the government was thus translated by the West first, as a destruction of the Islamic identity that defined Pakistan and secondly, as a potential threat of assimilation with India. Therefore, it was necessary to suppress this so called 'proHindu nationalism'. The military crackdown on 25 March started the Bangladesh War of Independence, with the Mujib's declaration of Independence on 26 March 1971. The ensuing war resulted in 3 million deaths in 266 days, in one of the worst genocides of the $20^{\text {th }}$ Century, with the war ending on 16 December. ${ }^{72}$ All these events are evidence of how the idea of

a major role in organizing and regulating liberation war. At present, AL forms the present government of Bangladesh.

${ }^{69} \mathrm{Lau}(\mathrm{n} 64) 195$.

${ }^{70}$ Sirajul Islam, "Election", online: $<$ en.banglapedia.org/index.php?title=Election>.

${ }^{71}$ See, Constitution of the People's Republic of Bangladesh, 1972, Schedule V.

${ }^{72}$ Ministry of Liberation War Affairs of Bangladesh, "Brief History of Liberation War", online: $<$ www.molwa.gov.bd/ >. 
building a multicultural nation, based on a single religious identity marker, can be doomed from the outset.

The following part enquires into the history of post-1971 independent Bangladesh. It discusses how the Bangladesh constitution embraced a secular policy at the beginning, but with the passage of time leaned towards favoring religion. Eventually, Islam became the state religion, which, standing alongside the secular mandates of the constitution, created a dichotomy, as these concepts are apparently mutually exclusive.

\section{PART III: BANGLADESH ERA: FROM SECULARISM TO ISLAMIC-SECULARISM} (1971-2011)

\section{A. Inception of an Era of Secularism and Subsequent Shifts towards Religiosity}

The liberation war of 1971 was not fought only for socioeconomic emancipation, but also to protect the secular cultural identity from the West Pakistani ruler. Thus, the country of Bangladesh emerged based on secular-socialist principles. The elected representatives of the 1970 election formed the Constituent Assembly under the leadership of Sheikh Mujibur Rahman to formulate the Constitution of Bangladesh, which was finally adopted on November 4, 1972. The constitution, by acknowledging the pre-independence socioeconomic, cultural and political contexts, declared nationalism, socialism, democracy, and secularism as the fundamental governing principles for Bangladesh. In particular, secularism was adopted because the use of religion in politics had resulted in enormous political upheaval and communal violence. Moreover, it was necessary to bar religion from occupying a political space within Bangladesh, to ensure the solidarity of multi-religious and cultural identities. This cautiousness was reflected numerous times in the speeches of the members of the constituent assembly during the 
deliberation for adopting the constitution. ${ }^{73}$ Consequently, to ensure this secular constitutional order, under the constitutional mandates, the AL Government banned all pro-religious political parties. ${ }^{74}$ The political strategy of AL was to gain popular support by establishing an ideological hegemony based on linguistic Bangalee nationalism and secularism.

Political analysis shows that, gradually AL started losing popularity for failing to ensure steady economic success, deteriorating law and order, corruption and favoritism. ${ }^{75}$ AL's secularnationalist ideological hegemony thus needed to be substituted with stronger rhetoric. For this reason, Mujib (then President of Bangladesh), despite being a strenuous supporter of secularism and opposed to the use of religion, started using pro-Islamic statements in his speeches (such as stating that he was proud to be Muslim and that Bangladesh is the second largest Muslim country). Mujib was also recorded to have claimed that secularism, as reflected under Art 12 of the 1972 Constitution of Bangladesh, did not imply absence of religion. ${ }^{76}$ This was the beginning of the infiltration of religion into Bangladeshi politics. This is despite the fact that historical records and later-day political analysis notes that Mujib tried to demystify the use of secularism in national and international efforts to secure economic and political cooperation from various pro-American and Middle Eastern countries which refrained from giving recognition to Bangladesh as an independent state, which in turn affected the flow of international aid to and trade of Bangladesh. ${ }^{77}$ Thus, although prior to the assassination of Mujib (on 15 August 1975) the constitution kept its secular character, this event marked the 360-degree shift in the political culture of newly formed Bangladesh from pro-secular to pro-religious.

\footnotetext{
73 Abdul Halim (ed), Gono Parishad Bitorko, (CCB Foundation, 2015) 70.

${ }^{74}$ Ali Riaz, God Willing: The Politics of Islamism in Bangladesh, (Rowman \& Littlefield Publishers, Inc., 2004$) 5$.

${ }^{75}$ Ali Riaz, Islamic Militancy in Bangladesh: A Complex Web, (Routledge, 2008) 9.

${ }^{76}$ See Riaz (n 74) 5.

${ }^{77}$ See generally, Kamal Hossain, Bangladesh: Quest for Freedom and Justice, (University Press Ltd., 2013).
} 


\section{B. The Beginning of the Islamization of the Constitution (1977-2011)}

Following the death of Mujib, Bangladesh witnessed several coup d'états and eventually in 1976 General Ziaur Rahman (Zia) assumed power and declared Martial Law in Bangladesh. This was the turning point towards the formal introduction of religion into politics through the Constitution. To legitimize his usurpation, Zia targeted the Constitution as a means to attract the majority of Muslims of Bangladesh. ${ }^{78}$ In 1977, Zia amended the governing principles of the constitution and made some significant changes: the introduction of Bangladeshi nationalism in place of Bangalee nationalism to distinguish people of Bangladesh from Indian Bangalees who are mostly Hindus; replacing secularism with absolute trust and faith in Almighty Allah; defining socialism as a means to achieve economic and social justice (analogous to the social justice concept of Islam); and, finally, inserting bismillah-ar-rahman-ar-rahim on the top of the preamble of the constitution. ${ }^{79}$ Later, having formed his political party, the Bangladesh Nationalist Party (BNP), and becoming president by means of a rigged election, ${ }^{80} \mathrm{Zia}$ removed the ban on the pro-religious, political parties through the $5^{\text {th }}$ amendment to the constitution, which facilitated his alliance with pro-Islamist political parties to ensure his rule. Zia was assassinated in 1981 and succeeded by General Hossain Muhammad Ershad 1982. Ershad followed went one-step further and, for the first time, Bangladesh had a state religion (Islam) by way of the Eighth Constitutional Amendment introduced by Ershad in 1988.

While Zia's measures to use Islam can be seen as a strategy to achieve legitimacy for his apparently illegitimate reign, his could not be said to be a remarkable instance of state-centric Islamization process. Nevertheless, Ershad's regime is marked by several initiatives to impose

\footnotetext{
${ }^{78}$ See Ali Riaz, 'The Politics of Islamization in Bangladesh' in Ali Riaz (ed), Religion and Politics in South Asia, (Routledge, 2010) 45, 48.

${ }^{79}$ Riaz,(n 74) 20.

${ }^{80}$ Riaz (n 78) 48.
} 
Islam on secular Bangalee culture: banning the drawing of Alpona ${ }^{81}$ in the Language Martyr's day observation because of its similarity to Hindu/Indian culture. ${ }^{82}$

Ershad eventually had to relinquish his position in the face of a massive anti-autocratic movement in the 1990s. However, despite the reinstitution of democracy, Islamic components inserted into the constitution were never removed. In fact, both BNP and AL showed an inclination towards forming alliances with the Islamist political parties. ${ }^{83}$ Moreover, during the martial law periods and subsequent democratic regimes, another factor became increasingly noticeable: heightened violence against religious minorities of Bangladesh. The number of religious minorities dramatically decreased (some argue that they were forced to flee) ${ }^{84}$ and since then their number has hardly ever increased. ${ }^{85}$

It is a question worth pondering why state religion was never removed from the constitution. The following section will discuss that question in detail by showing that the coexistence of state religion and secularism in the same constitution created a complex situation which ended the smooth application of secular constitutional mandates.

\footnotetext{
${ }^{81}$ Colorful lines and designs drawn on the surface of Language Martyr's Altar.

${ }^{82}$ Dina Mahnaz Siddiqi, 'Political Culture in Contemporary Bangladesh: Histories, Ruptures and Contradictions' in Ali Riaz and C Christine Fair (eds), Political Islam in Bangladesh, (Routledge, 2011) 7, 19.

${ }^{83}$ Riaz (n 74) 46.

${ }^{84}$ See Atanu Mohapatra \& Prakash, "Violence Against Minority Hindus in Bangladesh: An Analysis," online: $<$ www.vifindia.org/print/2200>.

${ }^{85}$ In 1974, Hindu minorities' forms 13.4 percent of the total population, while the Muslims forms 85.4 percent. However, at the end of Martial law regime (1990's) the number dramatically decreased to 10.5 percent and, in 2011, the number dramatically decreased to 8.5 percent while the number of Muslims population increased to 90 percent, see, Bangladesh Bureau of Statistics (BBS), Population Census Report 1991, (Bangladesh Bureau of Statistics, 1991), BBS, Literacy Assessment Survey 2011, (Bangladesh Bureau of Statistics 2011) .
} 


\section{a. Advent of Islamic-Secularism through Co-Existence of Secularism and the State}

\section{Religion Clause}

The constitutional accommodation of theocratic features continued until the $15^{\text {th }}$ Constitutional Amendment was passed in 2011 pursuant to a landmark decision ${ }^{86}$ of the Supreme Court of Bangladesh, which declared the $5^{\text {th }}$ Amendment introduced by Zia to be unconstitutional. The $15^{\text {th }}$ Amendment reinstated the original four fundamental principles (nationalism, socialism, democracy and secularism). But it did not remove Islam as the state religion in Art 2A 87 and "bismillah-ar-rahman-ar-rahim" over the preamble.

While the legislature's reason for keeping these religious idioms was an effort to recognize religion in symbolic form, if examined carefully one will find a clear inclination towards political compromise. By adopting this peculiar Islamic-secularism, the Government tried to avoid agitation from the Muslims community, while keeping room for political negotiation with Islamist and secular forces.

In sum, Bangladesh started its journey as an independent nation with a calculated move to prevent any element he constitution from motivating communal politics that might reignite the violent consequences of religious disputes evidenced in $20^{\text {th }}$ century South Asian history. The fear was that Bangladesh would be exposed to similar situations again by accommodating religion in the constitution as a political element, taking into account ideological motivators (Muslims). This time, however, the mechanism used was not only peculiar but also deceiving,

\footnotetext{
${ }^{86}$ Bangladesh Italian Marble Works Limited v Government of Bangladesh (2006) 1 BLT (HCD) (the Supreme Court of Bangladesh).

87 The state religion of the Republic is Islam, but the state shall ensure equal status and equal right in the practice of the Hindu, Buddhist, Christian and other religions, see, Constitution of the People's Republic of Bangladesh, art. $2 \mathrm{~A}$.
} 
because the mode of religious patronization has been concealed under the shadow of secular principles.

\section{Conclusion}

This article briefly summarized the political history of Bangladesh and analyzed significant phases of that political history (British colonization, the post-British Pakistan era, and Post-Independence Bangladesh Era until present). The article showed how, in each of these periods, religion was used as a means to an end to gain political advantages.

In light of this historical analysis, this article provided some clear context for the reader as to how religion is seen and interpreted in Bangladesh in terms of governance structures and politics. Moreover, this analysis is vital for finding the answer to the question of whether or not state religion is compatible with secularism, because history demonstrates that the use of religion for political purposes is never suited to this region. This article also showed that, whenever any religion was given any special recognition, or whenever religion was used for political advantage, (even if the motive was good), negative consequences ensued. Without exploring the full record that illustrates the problems with religion in this region, it would have been difficult to answer the question that everyone is asking for a while in the post $15^{\text {th }}$ amendment scenario whether the state religion clause in the present Constitution of Bangladesh will disrupt its secular mandates or indirectly instigate divisions or violence in society. 